\title{
Writing Family Life: A Feminist Inquiry into the Autobiographical Self in Cathy Song's Picture Bride (1983) \\ Reda A. Shehata
}

\begin{abstract}
\end{abstract}
This paper contends that Picture Bride (1983) - by the contemporary American poet of Asian descent Cathy Song (b.1955) - contains distinctive autobiographical lyrics about her family. Reflecting a feminist consciousness, the "autobiographical paratext" of her poems reveals interesting pictures of her family members. She writes with sympathy about her grandparents' transpacific journey to the States and the hardships they suffered in the plantation in order to establish a family. And she records with understanding the process of transformation by which they became American citizens, thus allowing their children and grandchildren to live the American dream. And she uses two of the most important techniques of autobiographical art to access their past: looking at photographs of some of them and recalling her lived experiences with them. The final aim of her voyage to the past is both selfdiscovery and self-recognition. And her narratives about them are colored with emotions and meditations and blend with her distinctive vocabulary, images, and rhythms to create her special autobiographical lyric poems.

Key words: family— autobiography—feminist—self 


\section{Writing Family Life: A Feminist Inquiry into the Autobiographical Self in Cathy Song's Picture Bride (1983) \\ Reda A. Shehata}

In its broadest sense, autobiography is the individual writer writing about himself. As a work of literature, it "describes a voyage of self-discovery" by tracing "through the alert awakened memory continuity from early childhood" (Buckley 40) to the present moment of writing. It springs from the "joy in self-communication," the desire for showing "sympathetic understanding of others," and the "need for self-assertion" (Misch 4). Mainly limited to "prose narrative" (Lejeune 4) since its inception, autobiography was expanded to include different literary works which, "despite their fictiveness," deal with "the same problems of self-definition that have taxed autobiographers since Augustine ${ }^{1}$ discovered that the self is a hard ground to plough" (Spengemann xiii).

Because of that expansion, lyrical poetry started to be approached from an autobiographical perspective. For example, a short lyric like William Carlos William's "The Red Wheelbarrow," a long poem like T.S. Eliot Four Quartets, and even a volume like Thomas Hardy's Moments of Vision are now read in autobiographical terms (by Stephan Kjerkegaard, James Olney, and Tim Dolin respectively). The working definition that Kjerkegaard offers of an autobiographical lyric poem can account for what is common between these different works. A lyric poem, he says, can be defined as autobiographical when "the author's name and that of the speaker converge" or when "its paratext must be defined as autobiographical" (186). An autobiographical lyric, he adds, is rooted in "events in the poet's life" where those events are presented in a reduced "narrative" manner which blends with the lyric poem's "lyricality and use of poetic devices" (189-190) which should be emphasized.

\section{ELLS Vol.9 No.I (364) SPU December 2018}


Reda A. Shehata

Feminist critics contend that autobiography is one of the dominant modes of women's writing. Celeste Schenk, for example, speaks about the "'autobiographical status'" of women's poetry which "hastens the undoing of a Western generic practice based on exclusion, limit, hierarchy, taxonomy, and formal norms" (287). And Sidonie Smith points out that the female autobiographer "establishes the discursive authority to interpret herself publicly in a patriarchal culture and androcentric genre that have written stories of woman for her, thereby fictionalizing and effectively silencing her" (45). However, woman's autobiography remains different from man's. The first feminist theorist of autobiography Estelle. C Jelinek argues that the difference between male and female autobiographers is that while the formers tend to focus on their professional lives, seeking "universal importance," the latter emphasize their domestic and personal ones intending to reveal "self-consciousness and a need to sift through their lives for explanation and understanding" (15).

Other feminist scholars of autobiography explain that woman's focus on the personal and domestic is an attempt by her to understand herself through her engagement mainly with an "other." Bella Brodzki and Celeste Schenk write that the "pervasive characteristic of female autobiography" is the woman's "selfdefinition in relation to a significant other" (8). And Tess Cosslett, Celia Lury, and Penny Summerfield argue that the "narration of the self cannot be understood in isolation from an other it acknowledges, implicitly or explicitly, and with which it is in a constitutive relationship" (4). Writing in relation with an other usually stems from woman's realization that the "self" is mainly "based in, but not limited to, a group consciousness - an awareness of the meaning of the cultural category WOMAN for the patterns of women's individual destiny" (Freidman40- 41-author's capitalization). Mainly, this "other" is her inner circle or her immediate family. Emphasizing the "psychology of gender socialization within the family," Nancy Chodorow argues that

\section{ELLS Vol.9 No.I (365) SPU December 2018}


"basic feminine sense of the self is connected to the world" (169), defined more in terms of relation and connection. For the female self, the family becomes a place where memories of its members are mediated; where social change is reflected; where tensions are lived and resolved, where the past and the present coalesce. By "grounding" her "identity in terms of her relation" to them, she is able to "write openly about" (Mason 210) her self. Therefore, she searches for lost episodes in their stories and pieces them together into her narrative or the "self-positioning act of [her] writing" (Benstock 1). By positioning herself much with and less against them, she tries to discover not only who she is but also who they are.

In Picture Bride (1983), the Asian American poet Cathy Song $^{2}$ (b. 1955) adjusts stories of her family in order to discover who she is. She sets herself with and against them to know her identity - as part of theirs - realizing that that "group consciousness" is what enables her to write openly about her self. To write about her self in relation to them, she revisits their past rejoicing in communicating with them while also showing sympathetic understanding of them. She uses her voice to express their identity in terms of who they are, where they are, when they are, how they became to be what they are-to rephrase the words of Meena Alexander (qtd. in Adams Asian American Literature 1). Her pictures of them become "historical markers" (Altieri 71) of their particular ethnic experience, which "historical narratives" try to "distort or omit." She seeks to "correct or refine" those "narratives" by making "visible the invisible nature" (Wong 3) of their ignored experiences figuring out how those experiences defined their past and still shapes her own present. Thus, she feels comfortable registering the tales of her Asian grandparents, taking us into their world, describing their suffering and sorrow as they worked on the sugar cane plantation of Hawaii at the turn of the previous century - specifically she identifies her self in their tales trying to

\section{$\begin{array}{llllll}\text { ELLS Vol.9 No.I } & \text { (366) SPU December } 2018\end{array}$}


Reda A. Shehata

draw strength and courage from them. In addition to her grandparents, she brings together tales of her parents and other family members seeking to sort out the meaning of their past experiences. And her narratives of her family blend with the lyricality of her poems - what Kjerkegaard calls "the poetry component"(191), in terms of vocabulary, images, and rhythm-in order to create a "poetry that is both expressive and autobiographic" (287) at the same time, according to Olney.

The "autobiographical paratext" of her lyric poems is presented through some of the most important techniques used in autobiography: looking at photographs of some family members and recalling tales she knew as a child. Lee-Von Kim believes that photographs are very crucial to autobiography as the two "share the same referential impulse, promising to document a past" (402). James Olney considers recall along with recapitulation as two important techniques at "the very essence of autobiography" (262) — as a technique, recall involves "two 'selves'": "'the self then," which lived the past and the "self now," the mature poet "doing the writing (Cosslett et.al.8). Those techniques become effective for a re-definition of Song's family's past. The photographs she looks at unveil specific moments in their lives, which though have become past are very crucial to an understanding of the present. She brings those past moments to the present to discover new meanings in both. For example, a photograph of her Korean grandmother, which she transforms into a verbal picture of her in "Picture Bride" (3-4), describes a particular moment in the past which has endured in the present. The poem reflects on the grandmother's departure from her home country to her new homeland for an arranged marriage with her Chinese grandfather. Because of the limited possibilities of the photograph as a "manufactured image" (Adams Light Writing 5) except for the grandmother's age and her "tent-shaped dress," there is not much that the picture can tell about her - the poem's narrative remains unfinished. Therefore, the poem, which is written in free verse and uses ordinary language, begins with a factual statement

ELLS Vol.9 No.I (367) SPU December 2018 
which is followed by three rhetorical questions. However, much can be guessed from those questions about the grandmother's journey. Each question becomes part of the "evolving picture" of her, part of "the process of searching" which is "inevitably a process of constructing" (Fujita-Sato 49-50) of that grandmother's identity as a picture bride ${ }^{3}$, as a woman chosen from a picture to be the wife of someone unknown to her.

Song once said that she wrote this poem as a "love letter" (qtd.in Tiedt 14) to her grandmother. And from the beginning, she seems to identify a bit of herself in her grandmother's story in terms of their relative age: "She was a year younger / than I, / twenty-three when she left Korea." Behind her reference to her grandmother's age, there is a feeling of sympathy relating to the uncertainty of the latter's new life-probably with little or no education, she has come to marry a man whom she knew only from a picture, unlike her granddaughter who now has good education and is married to a man of her own choice (Song had a master degree in creative writing from Boston university in 1981and was married to physician-intraining while living there). Because she is reflecting on an incident she was not a witness of, her use of the three rhetorical questions becomes imaginatively justified. By asking the first question, for example, she tries to envision the grandmother's motives for leaving her home country: "Did she simply close / the door of her father's house / and walk away"? Although Dyne wonders whether it was "defiance, or regret, or resignation" (190) that she left with, an economic reason ${ }^{4}$ - working in the plantation with her husbandremains possible for her journey to the new island, an island she has recently known its name, and on whose shore a man waited

turning her photograph

to the light when the lanterns

in the camp outside

Waialua Sugar Mill were lit

and the inside of his room

\section{ELLS Vol.9 No.I (368) SPU December 2018}


grew luminous

from the wings of moths

migrating out of the cane stalks?

The quick pace of the lines, their rising rhythm, and their mostly monosyllabic words establish a parallel between the migration of the grandmother from her original country to her new land and that of the "moths" from "the cane stalks" to the grandfather's room. If the lanterns' light suggests a primitive workplace, the "wings of moths" hint at an unromantic wedding dwelling. Until now she does not have a clear identity as she exits only as a "photograph." If the grandfather is somehow able to recognize her because he matches her appearance with the "photograph" he holds, he is for her a "stranger" who happened to be her husband, "thirteen years older than she." Once she looks at her photo being illuminated by the humble light of the night, she realizes the significance of her trip and who she will be in her new country. And he, in the meantime, is conscious of what the photograph promises for him: both an emotional and economic asset.

If by asking the second rhetorical question, the speaker weighs on what the grandmother took with her when she left her original country-hinting, perhaps, that what she carried with her would be a source of solace for her in her alien land-she, in the third, discloses more sympathy for her grandmother as she reflects tenderly on her (grandmother's) responses. The question depends on evocative vocabulary. The word "politely," for example, suggests decency while also indicating the grandmother's shyness from the stranger she was married to as a picture bride. The words "untie"reminiscent of "untying the knot"—and burning — suggestive of sexual desire-indicate the imminent consummation of her marriage. And her "tent-shaped dress" is now filled with the "dry wind" that soon will be followed by rain-a shift predicting the coming of offspring (the speaker included) - that the grandmother will give birth to. Suitable for the occasion, but unsuitable for "the climate," that dress "captures the commodified bride enacting the

ELLS Vol.9 No.I (369) SPU December 2018 
translation between the old world and the new, the class-inflected, racialized, sexualized, process" of this grandmother "becoming immigrant Asian local in Hawai'i" (Dyne 191).

The third question also hints at the speaker's admiration of her grandmother's strength and courage that enabled her to carry on with her new life against all odds. The picture bride generation represented for Song's generation "inner strength and fortitude necessitated by the physical hardship and psychological strain" (Kyhan 27) of the plantation experience. It is that strength of character that the granddaughter hopes to imitate to carry on with her life as a woman and as a poet. So it is true, according to Patricia Wallace, that Song "tries to recover a fuller sense of the grandmother's life, to see beyond the boundaries" of her photograph. But it is not true that the grandmother's life is "beyond the reach of the poem's images" (11) because the few scraps that Song collected about her are rendered imaginatively in the few but suggestive images of the poem. This critic's claim about the final images of the poem - the image of the grandmother's untying of the silk bow of her "jacket" and that of the wind blowing from the sugar cane fields - is not also to the point. It is not true that the second image means that the grandmother evaporates from the poem as she disappears into the Sugar Mill fields. It means that soon after her arrival and the consummation of her marriage she will be part of the plantation system and founder of a family out of which a grandchild would rise and save her memory from erasure from history contrary to this critic's claim. And the grandchild just did this by looking at the grandmother's photograph. Therefore, Eunha Choi's question about whether indeed it was an "actual photo that animated the poet's desire to pen this poetic storytelling" (52) may be questioned because like other poems, this one was inspired by a real picture of the grandmother as Song, who considers herself "the family chronicler" (qtd. in Eddy, n.p.), admits. And the poem becomes not only a description but also an "interpretation of [that] photograph"

\section{ELLS Vol.9 No.I (370) SPU December 2018}


Reda A. Shehata

(Dyne 189) that reveals its symbolic import to the speaker as a poet - she writes about that photograph to save a piece of memory from her family's history from sinking into oblivion.

The "visible" has then become "readable" (Mitchell 83) and the "readable" has become "visible" on its own terms. If the former is a "message without a code"(Barthes 19), a mere transcript of visual reality, the latter is a message with its own code (language), a verbal re-construction of that visual reality. And the same technique of representation is used again in "Untouched Photograph of Passenger" (59-60), a poem, read as a twin of the previous poem, which is also inspired by a photograph of Song's grandfather. For dearth of real details about his transpacific journey to the States, Song also depends on her imagination to construct her evolving image of him. From the physical details of his passport photograph - taken for the purpose of his cross ocean journeySong reflects on his intention and future prospects. If his photo documents "a given moment in real time" which is "followed by continued absence" (Choi 55), the picture that Song depicts of him will secure him a continued presence (in her poetry, of course). If the photographed picture of him makes him a living memory, that memory may be erased by time. But the verbal picture that Song makes of him, her artistic recognition of him, will defy time.

Accessible language, shorter lines, and evocative images define the poem's narrative string. From the speaker's narrative, the grandfather is guessed to be not "more than twenty." Her description of his physical features suggests a bright mood: his hair is "black and shiny / like a patent leather," his "cheeks are full," and his baby face has a "pockmark / above his right temple / about the size of a rice kernel." But the imperfect suit that the tailor made for himperhaps, it was "stitched" in a shop that hovered "in a back alley"is saved by the silk tie that "added touch" signifying the serious purpose of that picture. It was his "first important photograph" that documented "his passage out / of [his] deteriorating village" to his new world."

\section{ELLS Vol.9 No.I (371) SPU December 2018}


Although at the moment he appears fixed in the photographer's dark room, he is looking ahead "beyond the noisy clattered streets / pungent with garlic and smoked chestnuts." $\mathrm{He}$ looks beyond the photographer and his immediate surroundings, beyond his Asian heritage to a future in the making. If the photographer's view is limited, Song's is not because she is able to look beyond the photographic details. So if the photographer captures his physical features, Song reflects on his internal motives: "He will save it / to show his grandchildren./ As if already imagining them." With the photograph, he "aspires to pass" to his grandchildren "a piece of memory, a materially recorded moment of his history that could not otherwise be authenticated with undisputed uncertainty" (Choi 55-56). But with her picture, Song is certain she wants to save a past moment, which was lived in a different geography with a specific history, from sinking into oblivion. She wants to do so because that moment would affect not only the photographed grandfather but also his lineage. If the photographer made a photograph that was stuck in time, the poet is making a verbal picture that will not be time-bound. Hers will become a piece of history to be pieced together with other pieces to give a sense of who she is and who her ancestors were.

The grandfather features again in "Easter: Wahiawa, 1959" (7-9), but this time recalled from Song's childhood memory of him as an Asian immigrant engaging in the process of "transformation," of "becoming American" (Schultz 270). And the date in the title becomes significant as it marks a moment of change in the history of Hawaii's when it became a state-thus facilitating that transformation. If the photograph in the previous poem marks his passage from Korea to the sugarcane fields of Hawaii-what Benzi Zhang calls "the rehoming process" (5) - the verbal representation Song makes of him in this poem signifies his embrace of his new identity. And within a familial setting that marks that change, Song creates a contrast between his old and new identity in terms of egg

\section{ELLS Vol.9 No.I (372) SPU December 2018}


Reda A. Shehata

hunting: back at home he, as a poor person, used to collect quail eggs to eat on the riverbank, and now his grandchildren, comfortable in their lives, hunt for colored eggs on the Easter occasion. While touching on "the socio-historical framework" (Fujita-Sato 66) of the grandfather's immigration, the poem describes a "situation shaped by an Asian heritage, informed by the context and language of Hawaii', and influenced by features of contemporary American life" (Bloyd 398). As in many other places, the Easter occasion is associated with Easter eggs, hidden in the grass and hunted for by children.

And the narrative string of the poem blends with its free verse and accessible language to draw the speaker's picture of her grandfather. The poem is divided into two sections each recalling a past moment. The first moment captures the grandfather presiding over his grandchildren on the Easter occasion, and the second describes his transpacific journey to the plantation. And in the middle of the two moments is the speaker both as a child participating in the first moment and as an adult remembering and interpreting the two. The color blue becomes an important symbol in the poem. It signifies both the preciousness of the children's "treasures" (blue eggs) and the dignity of grandfather (suggested by his blue "whiskers"). And it contrasts with the color of the sky which is "a membrane of egg whites"—suggesting the impending storm that almost cancelled the celebration.

From a tender family atmosphere that the father captured with his camera, the grandfather is recalled. While the grandmother was hanging the laundry, the mother and aunts left the house carrying "the blue washed eggs." Meanwhile the grandfather kept the children - the speaker included-"penned in on the porch, / clucking at us in his broken English / whenever we tried to peek / around him." Though viewing him as a controlling figure with immense physical strength-his legs were "sturdy" and his right arm was large because of his long labor in the plantation-the speaker refers to his linguistic shortcomings. She says that his

ELLS Vol.9 No.I (373) SPU December 2018 
English is still broken because he clucks it in his Korean accent, though his clucking does not hamper the above-mentioned process of transformation. The speaker looked from him to the sky while the Easter egg hunt was threatened by the "storm." But the children's anticipation-hers included-did not last for long. Once the mothers were done with "planting the eggs / around the soggy yard" they broke free from the grandfather's hold on them-also suggested is their breaking free from his style of life as an immigrant to their style of life as Americanized grandchildren. They "dashed and disappeared / into bushes, / searching for the treasures"- the blue colored eggs that the grandmother "simmered in vinegar" all morning. The poem's narrative displays a parallel between the children's present hunt for eggs and the grandfather's past hunt for them in Korea. But his "treasures" were not as big as theirs: his long walk to the riverbank yielded him only "a quail egg or two." So he moved.

But this far-reaching memory, which is based on little details that Song gleaned from scraps of family tales, is linked to another memory. If he walked to the river back home searching for few "treasures," his other "long walk" through the "sugarcane fields" of Hawaii secured him plenty of "treasures," which were truly hardwon. And his first short walk is now replaced by his grandchildren's though in a different setting that will yield them plenty of "treasures." However, the present moment was embedded in the past one that held for the grandfather a future they now embody. Their walk is done for fun, but his was done for a serious purpose. The speaker seems to appreciate her grandfather's labor because it has become fruitful (in terms of financial security and family founding). She says that each walk he made and each "stalk that fell" brought him to the present moment, where he was "enclosed, / by his grandchildren, / scrambling around him...". The stalks have become a symbol of his fruitful labor that made him a capital asset to the

\section{ELLS Vol.9 No.I (374) SPU December 2018}


family: now he could buy them "crateful of oranges" and "basketful of sky blue eggs."

So his journey from the riverbank to the sugar cane fields has landed him in such a comfortable setting. He was relocated on the porch where, while keeping a watchful eye on his grandchildren on that occasion, he peeled for the speaker "marine-colored shells" from the hard-boiled egg. The last image of the poem describing the "shells" scattered on his lap like "something" that the ocean gives / the beach after a rain" suggests both his literal, bountiful gift as well his love gift to her. Two treasures were then given to her, one for her as a child and one for her as an adult poet reviewing the whole event. She now interprets that event in terms of "a gift of love given freely to a child, a gift entailing no obligation or requiring any knowledge of the labor expended to bring that egg hunt into being" (Fujita-Sato 68). Thus if the grandfather's gift represented his inexpressible love for her, she now answers back his gift by expending an imaginative labor to bring this poem to life as her gift of love to him.

That the grandfather's labor as well his granddaughter's are becoming more fruitful is clear in the domestic scene recreated from a photo of the father in "Father and Daughter" (33-34). Here his family is undergoing noticeable social changes. As the father appears to continue the process of assimilation that the grandfather started-enacting what Dyne calls "the American dream of a nuclear family, complete with a house and yard and new baby, supported by a regular job, with a day off to enjoy them" (192) - the daughter continues to strengthen her "small voice" to sing of her family. And the song she sings here features her father in admirable terms. The poem is structured again according to a narrative string, which is rendered in simple language, depends upon a number of metaphors (such as the father's "clean and fragrant handkerchief" and "Havana cigar"), and builds on some contrasts (between light and dark and work and leisure, for example). Sure this time of the scraps of her father's history, she moves from looking at his

ELLS Vol.9 No.I (375) SPU December 2018 
photograph holding her little sister-four years older than she-to an imaginative recreation of the domestic scene she would be an important part of later on.

The photo shows the father-an airplane mechanic-holding his little daughter in his day off. The speaker imagines that in the previous night he "crawled out" from the under of his airplane," wiped the "grease" from his hands, and paid farewell to his helpers, the two black boys. Though the speaker looks at his photo almost many years later, she can imagine the affectionate domestic atmosphere which it (the photo) evokes: she envisions the "sun" as he "posed in the backyard" and "the hot white light of Coral Gables / momentarily blinding" him and his little daughter "in a halo of light." The father appears relaxed in his "cotton undershirt" just as her little sister does in her "starched and sweet smelling" baby dress. And the mother in the background is "waving occasionally through" as she stands at "the screen door" with a " heart-shaped face smiling distractedly / As she wipes her hands on a kitchen towel"-an image suggesting that his leisure was made possible because she took care of all domestic obligations. If the image of the grandmother's dress penetrated by the wind in the sugarcane fields is one of potential, the image of this father's shirt is one of fulfillment. And the little baby the father holds in his hands, as a "clean and fragrant handkerchief" folded to his breasts / worth more than the money in [his] pockets," embodies his "middle-class aspirations," "underwrites his psychic propensity," and "confirms his masculinity" (Dyne 192). As a second generation Asian American, the father is proud of his paternity that is conceived in both American terms - as the metaphors of Havana cigar and his handkerchief suggest - and Asian ones - clear in his looking at his girl as his own asset.

To complete her picture of that relaxed domestic atmosphere, Song imaginatively recreates the father's return to his usual business in the "whale-shaped, / metal belly of" his plane. Dyne's remark that

\section{ELLS Vol.9 No.I (376) SPU December 2018}


he "at work is Jonah in the whale" (192) is partially to the point. Although it is a dark moment which contrasts with the glaring moment at the beginning, he is there for material reasons while Jonah was in the belly of the whale for non-material ones. Jonah's emergence from the darkness of the whale's belly to the light of the world becomes a metaphor for the father's emergence from the darkness of the plane's belly to the light of the American dream. And this emergence will be echoed in his second daughter's emergence from "the unlit room at dusk" to the light of the (poetic) world. Therefore, when he returns to his greasing business, a "flashlight propped in [his] mouth" because he was given that daughter (the speaker) as "a small voice" who will sing of him-and indeed of the whole family. She will transfer him from the darkness of the plane's belly to the luminous halo of her poetry. Now her arrival will snuff out her sister's "pink candles," a source of joy for the father at the moment. This is because some years later this younger sister will be the family's source of pride not only because she is produced by her father, like her sister, but because she will be produced by her poetry - an added advantage to her as a member of that family.

The father's photo remains as a reminder that he once lived there - in the domestic space-and is going to live somewhere else - in the artistic space, the poem itself. But someone could be also Song's mother whom she represents in wonderful pictures based on real life experiences with her, now warmly remembered. The mother was the center of the family in whose struggle for its preservation the daughter usually found an example to be honored and appreciated. In "A Pale Arrangement of Hands" (75-77) she relies on her memory as a psychological tool to reflect on her relationship with her as a devoted mother and a caring parent. And she does it in terms of the image of hands in connection with other relevant images such as rubbing, patting, soaping, and scrubbingall are suggestive of the mother's uninterrupted domestic labor and her maternal compassion and care. In this verbal representation of

\section{ELLS VoI.9 No.I (377) SPU December 2018}


the mother, Song makes an association between her own hands and her mother's. Such an association implies that her "poetry is rooted in her mother's skills" in spite of the different "expressive capacity" (Fujita-Sato 65) of each one of them: the mother's skills were translated through the medium of her housework, while the daughter's skills are now translated through the medium of language. And the language of this poem-like the previous onesis accessible reflecting also Song's usual narrative string through which the mother's picture is presented. Consisting of six stanzas of varying line lengths, this free-verse poem is characterized by a shift of tenses which indicates how the present reality of the speaker is shaped by her past experience with her mother.

Presently, the speaker is alone at home. It is a rainy nighttypical of Wahiawa, Song's Hawaiian birthplace. She looks at her hands on the "kitchen table" with their "white yellow" knuckles that appear like "tendons of a drumstick." Meanwhile her skin is "pulled taut to make a fist"- both images connoting her domestic as well as artistic skills. And she then remembers her mother's hands:

how nervous they always seemed

except when they were busy cooking.

[They] would assume a certain confidence

then, as she rubbed and patted butter

all over a turkey as though

she were soaping and scrubbing up a baby.

Prompted by the sound of rain and the sight of her hands, this remembered scene frames the mother's hands in terms of idleness and work: like an artist's hands, they were "nervous" when idle and confident when active. The sight of her while preparing that famous dish bespoke dedication and skill. And the link Song makes between the "turkey" and a "baby" suggests that the "essence of [her] motherhood" lies in her hands which "work, serve," and "create." Song also makes a wonderful association between the mother's care and compassion and the falling rain that enveloped her Wahiawa

\section{$\begin{array}{llllll}\text { ELLS Vol.9 No.I } & \text { (378) SPU December } 2018\end{array}$}


home. Like rain that constantly fell, the "mother's love was gentle and constant. Rain and love surrounded" the family home and "wrapped the children in security" (Cobb 228).

Such a current rainy atmosphere also triggers another scene in which her mother socialized with her girlfriends, "housewives from the neighborhood" who shook their "umbrellas at the kitchen door." Hospitable, she also looked beautiful - the youngest of them, she was "slender" with "a bright red flower mouth, / being partial to Calypso Coral." Reflecting a wonderful "ease of observation," the adult speaker's memory continues to release the evolving picture of her mother. She recalls with admiration another scene in which the mother skillfully did her make-up, showing how that artistic skill was not overshadowed by her domestic chores. A further scene is recalled in which she taught her children how to do another sort of art: making "artificial carnations / out of those discarded tissue / with a couple of hairpins." As a child, the speaker has been trained on that art-whose medium were "tissue" and "hairpins"—-but now she is training on another sort of art through whose mediumlanguage - she produces that tender image of her mother as a parent and as an artist.

Not only was the mother devoted, caring, and beautiful, but she was also disciplinarian. While preparing meals, she would let her three "lunatic" children watch "an hour of cartoons" or permit them to "drift through the house, / within its safe circumference, its comfortable geography"-an upbringing that promoted sound physical and emotional development of them. Like rain, her love fenced and protected her children. In other words, in an enclosed household, she gave the children some freedom to do certain activities like singing, playing, and drawing. But she was frustrated when they tried to deceive her (by refusing once to sleep in the afternoon, for example). Now alone, she is watching through the window the falling rain and then remembers that once "lying still"

but alert, I listened from the next room

as my mother slipped out of her damp dress.

\section{ELLS Vol.9 No.I (379) SPU December 2018}


the cloth crumpling onto the bathroom floor

made a light, sad sound.

The alliteration in "damp dress," "cloth crumpling," and" sad sound" strengthens the mother's evolving picture. It shows both the speaker's deft capacity for observation and her ability to translate it through the medium of language. A moment of spying on her mother's privacy has now become the substance of her poetry. And the "sad sound" of her dress on the bathroom floor has now found a sad echo in the daughter's artistic creation, sad because the mother's passion, support, and care for her children-in addition to her artistic skills - are now gone. This sadness may be also linked to the speaker's "awareness of her mother's unrecognized art" — contrary to her own art that is now in the process of being recognized-or to her loss of her childhood freedom, and now as a poet she "must practice the harsh discipline necessary for her art" (Cobb 230) or dedication to her craft that has been inspired by her mother's dedication to her domestic chores.

The mother is also recalled in "The Youngest Daughter" (56 ) in a central scene where she is being bathed by her daughter who thinks of leaving her. The poem's narrative is framed in free verse and is articulated in accessible language. Its language has roughhewn vocabulary such as "graveled," "gruff," "scrubbed," "sucked" etc. It is also built upon a number of contrasts: between "the drying sun" in the fields and the "sunless room" where the mother is showered, and the white body of the daughter and the brown body of the mother. And at the center is the wonderful, humorous image of the mother's breasts.

The interpretations made by Critics like Cobb and Kyhan of the poem in terms of tension between a freedom-seeking daughter and a tradition-maintaining mother-tension which is caused by what Lisa Lowe calls "generational discord" (36) - are acceptable. However, the two critics seem to miss the blessing of the domestic scene which reflects the speaker's sympathy for her mother in spite

\section{ELLS Vol.9 No.I (380) SPU December 2018}


of her (the daughter's) intention to escape. Because while the daughter complains that her skin has become "damp" and "pale" like rice paper due to her domestic chores, she does seem to be aware that her mother's hands experienced-and still experiences - the same because of her doubly executed chores in the house and in the fields. The mother's execution of those traditional chores had contributed to the family's transformation from potential to fulfillment, a fulfillment the daughter is now enjoying. She even describes her mother as a balm to the pain (resulting from executing those chores): she says how she (the mother) "has been massaging the left side of [her] face / especially in the evenings / when the pain flares up." Therefore, Cobb's positive and negative linking of the mother to pain (as a balm and cause of it) and her interpretation of the daughter's tone as one of accusation may be questioned. This is because if the mother's voice is gruff with affection, the daughter responds by being tender while bathing her. If there is tension, it is because of generational differences relating to Asian and American values. Though in an American setting, the mother still believes in "mind-forged restriction of filial obligations dictated by the Confucian tradition" (Kyhan 29) while the daughter embraces a free American style of life-differences which indicate how the family becomes a setting where the continuation of that tradition is contested.

At the center of the poem's narrative is the image of the mother's "great breasts":

when I wheeled her into the bath,

She was in a good humor,

making jokes about her great breasts,

floating in the milky water

like two walruses,

flaccid and whiskered around the nipples.

I scrubbed them with a sour taste

in my mouth, thinking:

six children and old man

\section{ELLS Vol.9 No.I (381) SPU December 2018}


have sucked from these brown nipples.

Images of floating and sucking signify the mother's reproductive capabilities - honored in Asian culture where children are conceived as valuable assets as mentioned before. And the image of the "flaccid" breasts suggests relaxation following long labor. If the sensuous nature of sucking is apprehensible as far as the relation of this mother to the "old man" was concerned, it remains contentious as far as her relation to this grown up daughter mattered. It may relate to the humorous atmosphere that the mother creates: the mother makes "jokes" about them and the daughter returns her "jokes" with the curious act of sucking them. And it may relate to this daughter's inner wish for physical reunion with her mother. Hence, the psychoanalytical, especially Lacanian, interpretation that Chen offers of this intimate physical scene may be relevant. That critic argues that the poem "displays a state of harmony as well as a nostalgic stage of bodily union between the mother and the child," adding that the "erotic character of the mother-child symbiosis is expressed by the poet speaker's nostalgic narrative of her response" to her mother's "sensual and palpable" body. Though the speaker appears to be nostalgic to that earlier stage, what Lacan calls the "imaginary relationship with the mother," she has to disjoin herself from her "to enter the symbolic, the social world" (584-586). She scrubbed them - a sign of her nostalgia - but found their taste sour - a sign of the necessity of dissociating herself from that nostalgia.

The daughter was "almost tender" and compassionate when handling the "blue bruises" resulting from insulin injection the mother underwent for thirty years. As she "soaped her slowly," the mother "sighed deeply" with "her eyes closed." This domestic ritual has been going on for sometimes in that "sunless room," which is reminiscent of the dark sky at the beginning-suggesting, perhaps, the hidden tension between the two. Because the mother was accustomed to an uninterrupted pattern of labor, she, after some rest,

\section{ELLS Vol.9 No.I (382) SPU December 2018}


Reda A. Shehata

returns to her daily ritual of preparing "tea and rice, / garnished with a shred of gingered fish, / a slice of pickled turnip." Both then depend on each other in the business of living although their relationship remains shaky.

The silence surrounding the meal foretells the daughter's intention to escape. The last image of "a thousand cranes curtain the window / fly up in a sudden breeze" is indicative of her intention. It foretells separation from mother, missing her compassion and care, breaking away from the traditional family values she represents. Sumida believes that the image evokes "longevity and marital happiness" (53) while Hugo views it in aesthetic terms, arguing that it represents the freedom available to the speaker through "visual imagination" (xiii). Cobb argues that it suggests a doubly conceived freedom, freedom from her paternal household through "marriage," and freedom through "art" (227) because the cranes are also artistic creations ${ }^{6}$. The mother's wisdom of life and her awareness of the penetration of American values into a setting still dominated by Asian tradition are clear in her distrust of her daughter's intention to stay. But if the daughter wants to escape this setting, she will remain part of this family picture as a caring daughter in relation to an old mother now in need of her help.

In section five of "Blue and White Lines after O'Keefe," titled "The White Trumpet Flower: Sun Prairie, Wisconsin " (4648), the daughter reflects on why she decided to leave her mother seeking freedom. She reveals that she left because of the mother's view of femininity, which centered on woman's physical beauty and dedication to domestic chores. In the voice of the famous painter Georgia O' Keefe ${ }^{7}$, Song imagines a dialogue between her and her mother in which she challenges her view while hinting at the mother's necessity for her artistic career.

The image of the mother's "red flower mouth" recalled in the previous poem corresponds here to the image of the "hems" of her "white dresses," decorated with "cloves and lavender and is strengthened by the image of "babies and detergent"-both

ELLS Vol.9 No.I (383) SPU December 2018 
reflecting her view of femininity which was challenged by the daughter. The mother is then remembered as being fenced in her beautiful clothes as well in her domestic activities. As the central image of the poem, fencing also shaped her relationship with her daughter (the speaker of the poem). The daughter was fenced in the playground to play with dolls as long as this made the mother happy. In addition, the mother has fenced her in "wide skirts" out of which she tried to crawl-both the skirts and the dolls emphasize the mother's view of femininity. The mother also fenced her in domestic chores, which have impacted her skin making it "parched and crinkled like a lizard's." And she tried to fence the daughter in a special frame of beauty: she tended to see her eyes in terms of a "crow's feet," while the daughter looked at them "as bird tracks, calligraphy in the sand." In short, the mother's style of upbringing was viewed by the daughter as constricting like a "porcelain flower vase." Thus her intrusion into the "mother's flowerbeds" to "crucify the dolls" and decapitate the "crocuses" signified rebellion against that style.

The daughter discovered her autonomy and left. And she kept despising her mother for years because of such a view of femininity. She sought freedom through marriage. But she found out that freedom through art would not be possible without reconciling with her mother. She realized that for her art to continue, it had to remain, ironically, dependent on her mother's presence in her life. Therefore, she has abandoned her "geographical / psychological flight (Lim 422) and has come to rest at her feet, "to be near the familiar scent of talc, / the ticking of the china clock, / another heartbeat"-while references to the "china clock" here and to the speaker's dolls and "her parched and crinkled" hands before signify her Asian heritage, they testify to her successful intertextual appropriation of $\mathrm{O}^{\prime}$ Keefe. She has come to recognize her life and to realize that on using her artistic medium, it is the mother's artistic skill that "declare[s] itself." Thus, in spite for her search for

\section{ELLS Vol.9 No.I (384) SPU December 2018}


Reda A. Shehata

independence from her mother's "defined feminine ways" and her revelation of the need to "live according to self-discovered values and an individual framework of perception," she finally seeks reconciliation with her, a reconciliation that can be based "not necessarily upon similarity, but upon acceptance and understanding," upon "the recognition of the art and strength in motherhood" (Cobb 231). She has come to understand, accept, and honor her mother's life in her poetry.

In her natural storyline, which reflects careful observation, translated in wonderful images and rendered in free verse, Song reconstructs through recall a tender image of another family member in "For My Brother" (16-17). She reflects on her relationship with him both as a child and as an adult poet making that portrait of him. With clarity and precision, she re-creates the pleasant domestic atmosphere in which the brother was born. She makes an association between the falling rain and his birth, creating a parallel between the generosity of nature and the blessing of having a child in an Asian American family. And the scene of his swimming in the stream suggests the blessings of that domesticity: moving gently out of "the broken water," he jumped into his "father's surprised hands" while the mother struggled to keep his "jellied body / cradled in her arm"-an image of passionate containment. For the speaker, he appeared like a little angel who swam through the air out of the "cage" of his "crib."

The speaker remembers that as a child she once clung to the bar of his "crib." Moved by the sight of his eyes, ears, and cheeks ("curved like slender islands"), she envied his "profile" that appeared "Egyptian and remote / like a delicate water-bearer of the Nile"-an image suggestive of a simple primitive beauty still untouched by the complexities of modern life. It is clear now that her representation of this little brother is done "through repetition of images of water, milk, rain, fish, and stream" which are linked to "swimming, diving, and jumping" (Chen 589). But if the little boy was once carried by the speaker (as a child) to the stream where he

\section{ELLS Vol.9 No.I (385) SPU December 2018}


dived "to navigate without words," the adult speaker is now able to navigate her memory with words to recall that past scene with him. As a child she observed him moving effortlessly and efficiently in the stream. Now as a mature person she knows that she moves in life differently, if not effortlessly but efficiently, because she has mastered the alphabet, her expressive medium that will bring out of her an "ocean" of love not only for him but also for the whole family. And this is her particular way as an artist of swimming through the "night waters" of life.

Recall, which is at the very heart of the "autobiographical paratext" of the poem, is relied on by Song to represent her little brother as a part of her ethnic family. That family is conceived in another poem as a "tribe"—in a poem of the same title (31-32) — of whose praises she (described as a "dove" in the same poem) sings to the mainstream American society. As an adult member of the family with a child consciousness, Song recalls also a warm experience with an elder sister who taught her the meaning of bravery and belonging to that tribe. If she and that sister as little children used hollowed "eggshells" to whistle their "noiseless tunes" to the outside world, she is now whistling her noisy "tunes" about that sister in her poetic world - just as she does with other family members. Like the previous poems, "Tribe," in addition to displaying a "naturalness of form, based unpretentiously on phrasal pauses or the breadth of a line, by an unforced storyline or ease of observation," has "a sudden eruption of metaphor" (Lim 98) which becomes illuminating. The metaphor here describes the speaker's arrival into the world in terms of a "song of the morning dove / spilling from the guava tree." And this little dove was warmly welcomed into the family: her grandparents "pinched and cuddled" her, "affectionately gruff, blowing garlic breath / Across [her] unflinching face" and lifted her into "their brown speckled arms." As the second girl in the family, four years younger than her sister, she, with an adult consciousness, now reflects on her moment of birth in terms of her Asian ancestry.

\section{ELLS Vol.9 No.I (386) SPU December 2018}


The protection she provided her little brother with in the previous poem is here given to her by that sister. At the moment of her birth, the sister appeared like a little Buddha," stern and protective. Like the "jellied" body of her brother, this sister's was "lithe / with the speed of a rabbit, quick and running." And the scene in which they played games with each other under their parents' protective eyes was nothing but Edenic: they "shared papaya boats" that the mother "emptied of black seeds / that resembled caviar" and the "eggshells" that the father "hollowed for whistles." And they blew their "songs to the gulch / that brought the eucalyptus smell of rain"-an image that suggests their communion with nature. Her sister's forays into the forest strengthened their filial association and romantic attachment to nature as the following image explains: the "lilikoi vines" - the Hawaiian name of that passionate fruit - that the sister has taken her to "dripped sticky sap passionately, / their blossoms curling like bells or tongues." If the sister was seen by the speaker as protective and caring, she is also remembered as a brave huntress: "the only girl in a gang of boys," she resolutely delved into the forest to have her precious hunt. And her sight when she returned with her "sunlit hunt" taught the speaker the meaning of courage and filial belonging.

And filial belonging essentially meant identification with a place that reflected Song's particular ethnic background. In "Leaving" (14-15) she recalls her family household, the plantation setting, and the restrictive weather atmosphere in the town of Wahiawa (her birthplace) reflecting a "distinct sense of place and attachment" (Hiraoka 21) against which the meaning of her family's life is perceived. It is the interrelation of the three worlds which she successfully re-constructs in this poem. If she has left the place, she still has strong memories of it. Therefore, she is now returning to "displace National Geographic," which her father subscribed to for ten years, "with her own experience-based pictures of the world, including new construction of the place she left" (Fujita-Sato 69). The poem, which is divided into four stanzas, shifts from the present

ELLS Vol.9 No.I (387) SPU December 2018 
moment of speaking to a moment in the past. The first two stanzas give two images of Wahiawa; one describing its present reality, the other recalling a past moment in it, and the last two offer an image of the domestic setting there, which was curtained by the common plantation weather.

"Wahiawa is still / a red dirt town," thus speaker narrates the town's specific geography, where the "sticky smell / of pineapples" in the fields rises to mix with "the minty leaves / of eucalyptus / in the bordering gulch." Her organic natural imagery marks a shift from the present to the past: it was there that the family household was located, surrounded by "orchids," "huge "as lanterns overnight," and decayed "passion fruits" on their vines - this last image counteracts the glaring atmosphere the first one evokes. Literally, rain fenced human activities inside the house: it "fell like a gray curtain / through which [the] mother peered." In spite of the restrictive weather outside, the children exercised their freedom inside as the speaker's narrative shows:

We built houses within houses,

stripping our parents' bed

of pillows and sheets,

erecting walls out of

The National Geographic

which my father had subscribed to

for years.

By subscribing to the famous magazine, the father seems to be completing the process of transformation, of becoming American. And by building "houses within houses" the children try to be far removed from the plantation world of their grandfather. Therefore, they "feasted / on those pictures of the world," which that magazine contained-indeed this is the bright moment in this recollection. But the outside weather was still a threat to their inner free world: while having their meal, mud covered "the drab green leaves / of palm fronds," "centipedes" appeared on the pipes, "and mold covered

\section{ELLS Vol.9 No.I (388) SPU December 2018}


Reda A. Shehata

their fingers "making everything slippery to touch," and they became "squeamish and pale." These last two adjectives describe the intrusion of the internal world of the children by the natural world, an intrusion which becomes also clear in the incident in which a bat scarred her little sister. But if this last incident-among many other things-justified "leaving" the whole place by the speaker, she is now returning to it with a new consciousness to reconstruct that image of it in order to emphasize her continued association with it.

So far, reflecting a feminist consciousness, the "autobiographical paratext" of Song's poems reveal sympathetic understanding of her family members. The photographs she looks at, the stories they evoke, and the feelings they generate set the scene for her "self-positioning act" of writing. Also recall helps her pin down her lived experiences with them-in those experiences, moments of harmony and intimacy figure more than moments of disharmony and struggle. Both techniques reveal how her family matters the most. She was like many in Hawaii (her birthplace) for whom family and community were so important, and as a poet of Asian descent she tries to comprehend the meaning of that family's past and to know her roots and understand the collective identity she is part of - the final aim of her voyage to the past is both selfdiscovery and self-recognition. Therefore, she writes with sympathy about her grandparents' transpacific journey to the States and the hardships they suffered in the plantation in order to establish a family. And she records with understanding the process of transformation by which they became American citizens, thus allowing their children and grandchildren to be ready to live the American dream. She feels obliged to narrate through her poetry long passed moments from their lives to give due recognition to their existence. She portrays them with an awareness that they may pass out without being fully appreciated. She, therefore, returns to the past to tell their stories to acknowledge "their ways of knowing and seeing the world" which "are rarely acknowledged, let alone

ELLS Vol.9 No.I (389) SPU December 2018 
celebrated, in the expressions of a hegemonic culture" (Kuhn 8). She reaches out with love and sympathy to depict their actual life in all its details because she wants to make sense of her family's dynamics and her role within it. And in the end, the narratives she makes are colored with emotions and meditations and blend with her distinctive vocabulary, images, and rhythms to create her special autobiographical lyrics.

Notes

1- Saint Augustine (354-430) was one of the Latin Fathers of the Church who, by adapting "classical thought to Christian teaching" managed to create "a theological system of great power and lasting influence" (O'Donnell n.p.). His Confessions (400) is believed to have started the "genre" (xiv) of autobiography according to Spengemann.

2 - To date, author of five collections of poetry-Picture Bride (1982), Frameless Windows, Squares of Light(1988), School Figures (1994), The Land of Bliss (2001), and Cloud Moving Hands (2007) — Cathy Song is an award winning poet. Her first book carried her to "national recognition" (Eddy, n.p.): it received the prestigious Yale Series of Younger Poets Award in 1982 and was nominated for the 1983 National Book Critics Circle Awardalso in 1993 she received the Hawaii Award for Literature and the Shelley Memorial Award from the Poetry Society of America. Her first volume was a "remarkable achievement" (Solberg 545) which had given her" sudden" and "glorious, visibility" that marked "the full-blown emergence of a major figure" in Asian American literature (Lim 95). Song is grouped together with pioneering Asian American poets such as Li-Young Lee, David Mura, Marilyn Chine whose particular style of poetry emphasizes "personal voice, epiphanic insight, and loose verse forms" (Yu Race 73). Characterized as first-generation Asian American poets, they, according to Victoria Change, "tended to focus on issues of culture,

\section{ELLS Vol.9 No.I (390) SPU December 2018}


Reda A. Shehata

identity, family, politics, ethnicity, and place" (qtd. in $\mathrm{Yu}-$ review223).

3 - Picture bride was a common method of arranging marriages before the Japanese Korean war. After exchanging photographs between the man and the woman, a marriage ceremony was held in the bride's home country and was followed by her departure to join her husband whom she saw "face-to-face" the first time. See, Fujita-Sato.

4 - Many critics have touched upon the connection between the familial and economic reasons behind the Asian females' picture bride immigrants to the States. See, for example, Dyne.

5 - Aspects of the change that the State of Hawaii underwent included - among many other things - diverse economic activities, cultural pluralism, and people's integration. See, for example, Takaki.

6 - The same link that Song establishes between origami and her poetry is again referred to in her poem "Hotel Genève" (69) where she speaks of folding secrets into pages of "a pristine journal" she kept as though she "were wrapping jade fish into origami."

7 - O' Keefe was a twentieth century American painter (1887-1986) who impacted the structure of Song's book. On the suggestion of the poet Kathleen Spivack (b.1938), Song reordered the book using O'Keefe's paintings as titles for its five sections. In addition to striving for "personal independence and artistic dedication" (Fujita-Sato 55), the two artists share a similar view of art which, they believe, is rooted their mothers' lives. Certain differences, however, remain between O'Keefe and Song: unlike the poet, the painter did not speak about reconciliation with her mother, and unlike Song, she lived in a world without "men" and "mirror." Therefore, Song intertextually appropriates clear references to the famous painter - such as her name, longtime home in Abiquiu (a ranching community in northern New Mexico) and her canvas-so that the poem remains to be essentially about her and her mother.

\section{ELLS Vol.9 No.I (391) SPU December 2018}


Writing Family Life: A Feminist Inquiry into the Autobiographical Self in Cathy Song's

Picture Bride (1983)

\section{References}

Adams, Bella. Asian American Literature. Edinburgh UP. 2008

Adams, Timothy Dow. Light Writing and Life Writing: Photography in Autobiography. U of North Carolina P, 2000.

Altieri, Charles. "Images of Form vs. Images of Content in Contemporary Asian-American Poetry." Qui Parle. Vol.9. No.1 (Fall/Winter 1995), pp. 71-91.

Barthes, Ronald. "The Photographic Message." Image/Music/Text. Translated by Stephen Heath. Hill and Wang, 1977

Benstock, Shari. Intr. The Private Self: Theory and Practice of Women's Autobiographical Writings. Ed. Shari Benstock. U of North Carolina P, 1988, pp.1-7.

Bloyd, Rebekah. "Cultural Convergences in Cathy Song's Poetry." Peace Review. Vol.10, No.3 (1998), pp. 393-400

Brodzki, Bella and Celeste Schenk. Intro. Life/Lines: Theorizing Women's Autobiography. Eds. Bella Brodzki and Celeste Schenk. Cornell UP, 1988, pp. 1-16.

Buckley, Jerome. The Turning Key: Autobiography and the Subjective Impulse since 1800. Harvard UP, 1984.

Choi, Eunha. "Bollaín's Flores de Otro Mundo via Cathy Song's Picture Bride: Photographic and Poetic Images Recreate the Art of Forming and Experiencing Community." Pacific Coast Philology. Vol. 51, No.1 (2016), pp. 42-65.

Cobb, Nora Okja. "Artistic and Cultural Mothering in the Poetics of Cathy Song." New Visions in Asian American Studies: Diversity, Community, Power. (1994), pp. 223-234

Cosslett, Tess. et.al. Intr. Feminism and Autobiography: Texts, Theories, Methods. Eds. Tess Cosslett.et.al. Routledge, 2000, pp.1-23.

Dolin, Tim. "Life-Lyrics: Autobiography, Poetic Form, and Personal Loss in Hardy's Moments of Vision. Vol. 15. No.1 (Spring 2012), pp. 119

Dyne, Susan R. Van. "Snapshots in History: Re-reading Ethnic Subjects in Cathy Song." Re-placing America: Conversations and Contestations: Selected Essays, Literary studies East and West.Vol.16. Eds. Ruth Hsu et. al. U of Hawaii P, 2000, pp.181-198

Eddy, John. "Cathy Song." Poetry Foundation. Available at:

ELLS Vol.9 No.I (392) SPU December 2018


Reda A. Shehata

$1,2018$.

https://www.poetryfoundation.org/poets/cathy-song. Accessed July

Freidman, Susan Stanford. "Women's Autobiographical Selves: Theory and Practice." The Private Self: Theory and Practice of Women's Autobiographical Writings. Ed. Shari Benstock. U of North Carolina P, 1988, pp.34-62.

Fujita-Sato, Gayle K. "'Third World' as Place and Paradigm in Cathy Song's Picture Bride." MELUS. Vol.15, No 1 (Spring 1988), pp. 4972.

Hiraoka, Jesse. "Asian American Literature." Dictionary of Asian American Literature. New Press, 1986, pp.13-21.

Hugo, Richard. Foreword. Picture Bride. pp. ix-xiv.

Jelinek, Estelle. C. "Introduction: Women's Autobiography and the Male

Tradition." Women's Autobiography: Essays in Criticism. Ed.

Estelle C. Jelinek. Indiana UP, 1980, pp.1-20.

Kim, Lee-Von. "Scenes of Af/filiation: Family Photographs in Postcolonial Life Writing." Life Writing. Vol.12, No.4 (2015), pp. 401-415.

Kjerkegaard, Stefan. "In the Waiting Room: Narrative in the Autobiographical Lyric Poem, or Beginning to Think about Lyric Poetry with Narratology. Narrative. Vol. 22, No. 4 (May 2014), pp. 185-202.

Kyhan, Lee. "Korean-American Literature: The Next Generation." Korean Journal. Vol. 34. No. 1 (Spring 1994), pp. 20-35

Kuhn, Annette. Family Secrets: Acts of Memory and Imagination. Verso, 2000

Lejeune, Philippe. On Autobiography. Translated by Katherine Leary. Edited by Paul John Eakin. U of Minnesota P, 1989

Lim, Shirley. Review. Picture Bride. MELUS. Vol. 10. No.3 (Fall 1983), pp.95-99.

Lowe, Lisa. "Heterogeneity, Hybridity, Multiplicity: Marking Asian American Differences." Diaspora: A Journal of Transnational Studies. Vol.1, no.1 (Spring 1991), pp. 24-44

Mason, Mary G. "The Other Voice: Autobiographies of Women Writers." Autobiography: Essays Theoretical and Critical. Ed. James Olney. Princeton UP, 1980, pp. 207-235.

\section{ELLS Vol.9 No.I (393) SPU December 2018}


Writing Family Life: A Feminist Inquiry into the Autobiographical Self in Cathy Song's

Picture Bride (1983)

Misch, George. A History of Autobiography in Antiquity. Psychology Press, 1950.

Mitchell, W. J. Thomas. Picture Theory: Essays on Verbal and Visual Representation. U of Chicago P, 1994.

O'Donnell, James. "St. Augustine: Christian Bishop and Theologian." Encyclopedia Britannica. Available at:

www.britannica.com/biography/Saint-Augustine. Accessed July 7, 2018

Olney, James. Metaphors of Self. Princeton UP, 1972

Schenk, Celeste. "All of a Piece: Women's Poetry and Autobiography." Life/Lines: Theorizing Women's Autobiography, pp. 281-305

Schultz, Susan M. "Cathy Song." Journal of Literary Biography. American Poets since World War 11. Vol.169. Gale,1996, pp. 267-274.

Smith, Sidonie. A Poetics of Women's Autobiography: Marginality and the Fictions of Self-Representation. Indiana UP, 1987.

Solberg. S.E. "Cathy Song and the Korean American Experience in Poetry." The Asian Pacific American Heritage Ed. George J. Leonard. Garland Publishing, Inc., 1999, pp. 541-546.

Song, Cathy. Picture Bride. Yale UP, 1983

Spengemann, William. The Forms of Autobiography: Episodes in the History of a Literary Genre. Yale UP, 1980.

Sumida, Stephen. "Pictures of Art \& Life." Contact 11 (Winter-Spring 1986), pp. 52-55.

Takaki, Ronald. A Different Mirror: A History of Multicultural America. Little Brown \& Company, 2008

Tiedt, April Melissa. "Framing Memories: Photography in the Poetry of Cathy Song." Diss. Angelo State University, 2002.

Wallace, Patricia. "Divided Loyalties: Literal and Literary in the Poetry of Lorna Dee Cervantes, Cathy Song, and Rita Dove." MELUS. Vol. 18, No 3 (Fall 1993), pp. 1-19.

Wong, Hertha D. Sweet. Picturing Identity: Contemporary American Autobiography in Image and Text. U North Carolina P, 2018.

$\mathrm{Yu}$, Timothy. Race and the Avant-Garde: Experimental and Asian American Poetry since 1965. Stanford UP, 2009.

---. Review. Asian American Poetry: the Next Generation. Ed. Victoria Change. U of Illinois P, 2004 Zhang, Benzi. Asian Diaspora Poetry. Routledge, 2008 .

\section{ELLS Vol.9 No.I (394) SPU December 2018}

